\title{
A FISCAL IMPACT MODEL FOR VIRGINIA COUNTIES
}

\author{
Brent M. Swallow and Thomas G. Johnson*
}

\section{Introduction}

Economic impact models provide a framework for analysts to forecast the economic, demographic, and fiscal consequences of particular economic shocks. Current models are generally composed of economic, demographic, and fiscal blocks or components organized recursively. The fiscal blocks are primarily designed to project the impact that a shock, such as the location of a new industry, will have on local government expenditures and revenues. They answer such questions as: will local taxes rise or fall, will expenditures increase; if so, will they increase more or less than revenue; the bottom line question is, will the local government be put in a surplus or deficit position?

Most economic impact models incorporate very rudimentary fiscal components (see Halstead and Johnson (1986) for a review of major fiscal impact models). Most assume that expenditures increase proportionately with population with no allowance for economies or diseconomies. Few models incorporate lags, assuming instead that all changes occur instantaneously. Some models aggregate expenditures to such an extent that potential capacity problems cannot be discerned from impact analyses.

While a few good economic impact models have been developed for states across the country, these models do not transfer well from one state to another because of differences in institutions. Furthermore, few models have been designed to consider the impact of annexation related changes. For these reasons, it was decided to develop an impact model for Virginia counties. This model, while no more transferable, would incorporate Virginia's numerous institutional oddities. This paper reports on the fiscal block of the model because it represents a significant departure from the fiscal components of many other models. In particular, it incorporates such aspects as size economies in public service provision, quality of services, the effects of adjustment lags, and variables related to annexation shocks.

The impetus for this model was the need to project the impact of annexation on a county. Virginia is unique in the United States with a statewide institutional structure of independent cities and

\footnotetext{
*Project Leader, Agricultural Marketing Research Project, Institute of Southem African Studies, National University of Lesotho, and Associate Professor of Agricultural Economics, Virginia Polytechnic Institute and State University.
}

counties. Of forty-nine independent cities in the United States, forty-one are in Virginia. This strict separation makes city annexation of county jurisdictions very contentious. All responsibility for the provision of public services as well as rights to tax are transferred from the county to the city. In their own interest, cities selectively annex adjacent county area. This contiguous county land is generally atypical of the overall county. Business and industrial firms predominate. These features are attractive to both city and county governments as they demand relatively low levels of public services while providing significant tax bases.

For this institutional setting, a robust impact model is necessary. Annexation represents a particularly sudden change in the circumstances faced by a county government. The county which experiences annexation loses tax base, tax revenues, population, school pupils, some expenditures and sometimes facilities and industrial sites. The impact of annexation, even the immediate impact, is unclear. The long run impact is even less clear, particularly since it depends so much on the reaction of the county to its new circumstances and the reaction of industry to the altered economic environment.

A county rebounding from an annexation must adjust in at least two ways. First it must adjust its facilities, personnel, and capacity to reflect the new, smaller population and area. This adjustment is not simply a matter of reducing the number of schools, teachers, workers, etc., since the annexation tends to disrupt the spatial order and equilibrium that previously prevailed. Second, new plans and strategies must be formulated. Revenue shortfalls may occur despite short-term compensation payments. Comprehensive plans must be replaced and industrial location strategies rethought since the focal point of its marketing strategy and often its best industrial sites are now part of the city. Furthermore, unless special provisions are negotiated, future annexations are very likely.

The short term consequences of annexation may be ascertained with a fiscal impact model. Because of the magnitude of the change and its suddeness, the model must pay special attention to the adjustment process as well as possible changes in public service quality, cost conditions and local and non-local revenues. Analysis of the longer term consequences of annexation require a more comprehensive economic impact model. The larger model projects reactions in economic and demographic variables. These combine to further affect the public service sector and the revenues and expenditures of the local government. 
(4) $\quad \mathrm{NLR}=\mathrm{d}(\mathrm{Q}, \mathrm{A}, \mathrm{D}, \mathrm{F}, \mathrm{P}, \mathrm{Z}, \mathrm{X})$

where NLR = non-local revenues per capita,

$\mathrm{Z}=$ local ability to pay

$\mathrm{X}=$ political influence.

\section{Local Revenues}

Local governments are forced to balance their budgets for current expenditures for time periods greater than the very short run. Therefore, borrowing and deficit financing are not considered in this model. Local governments must make up the difference between local expenditures and non-local government revenues with locally generated revenues. Locally generated revenues are gained from licenses, fees, penalties, interest on investments, but mostly from sales and property taxes. In Virginia, the sales tax rate is fixed at one percent of local sales. Property tax rates are determined locally, hovever, and in this model are assumed to equal the residual revenue needs after all other revenues are applied to expenditures. The following equation describes this view of the budgetary process:

(5) $(\mathrm{UC} * \mathrm{~A})=(\mathrm{NLR} * \mathrm{~A})+\mathrm{STR}+(\mathrm{PTR} * \mathrm{PTB})$

where: $S T R=$ sales tax revenue, PTR = property tax rate, and $\mathrm{PTB}=$ property tax base.

\section{The Empirical Model}

\section{Public Service Expenditure Functions}

The public service expenditure and revenue functions are estimated on a per capita and per pupil basis using seemingly unrelated regression analysis. This method was utilized to improve the efficiency of estimates since the regression equations are related through their error terms (Pindyck and Rubinfeld, 1976). This statistical relationship is due to the budgetary constraints faced by local governments. Increased expenditures of one type must be accompanied by reduced expenditures in others. All expenditure and revenue equations were estimated as a single system. Expenditure functions are estimated for eleven major groups of operating and maintainence expenditures. Administration and public works (largely maintenance of buildings and infrastructure excluding roads) are treated as overhead expenses and thus are modeled as dependent on levels of other expenditures. Expenditures other than school are summed (school systems generally have their own administrative personnel) and used to explain administrative and public works expenses. All expenditure and revenue data came from the "Comparative Cost of County and City Government," for the fiscal year 1980-1981.

Table 1

Expenditures by Category

\begin{tabular}{|c|c|c|c|c|c|}
\hline & $\begin{array}{l}\text { Fire } \\
\text { Protection }\end{array}$ & $\begin{array}{l}\text { Parks/ } \\
\text { Recreation }\end{array}$ & $\begin{array}{l}\text { Police } \\
\text { Protection }\end{array}$ & $\begin{array}{l}\text { Correction/ } \\
\text { Detention }\end{array}$ & Health \\
\hline Intercept & .3376 & $-16.343^{* *}$ & $-7.508^{*}$ & -2.0595 & $-8.0515^{* *}$ \\
\hline Population & $2.973 \times 10^{-4}$ & $1.736 \times 10^{-11}$ & $1.538 \times 10^{-4 * *}$ & $7.257 x^{10-5 * *}$ & \\
\hline Population $^{2}$ & $-4.602210^{-11}$ & $-2.388 \times 10^{-10 * *}$ & $-2.174 \times 10^{-10 * *}$ & $-1.321 \times 10^{-10}$ & \\
\hline$\% \Delta$ in Population & .3012 & & -.4764 & $-.7288^{* *}$ & \\
\hline Income/Capita & & $.00154^{* *}$ & $.00183 * *$ & $.001136 * *$ & $.001958 * *$ \\
\hline Prop Value/Capita & & & & & \\
\hline Population Density & & & & -.00174 & \\
\hline Miles to SMSA & & & $-.05987^{*}$ & & \\
\hline Crimes/Capita & 47.058 & & & & 40.067 \\
\hline Solved Crimes/Capita & -.02378 & & $4.441^{*}$ & 9243 & \\
\hline $\begin{array}{l}\text { Fire Protect. Rating } \\
\text { Miles of Road }\end{array}$ & & & & & \\
\hline $\begin{array}{l}\text { Miles of Road } \\
\text { Ratio Prof/Volunteer }\end{array}$ & $\begin{array}{l}-.0004006 \\
.4388 * *\end{array}$ & & & & \\
\hline$\%$ With Diplomas & & $.1104^{*}$ & $.15784^{*}$ & & \\
\hline Infant Mortality & & & & & -.0213 \\
\hline Percent Non-White & & & & & -.008479 \\
\hline Unemployment Rate & & & & & .09727 \\
\hline $\begin{array}{l}\text { Total Exp/Capita } \\
\text { (Total Exp/Capita) }^{2}\end{array}$ & & & & & \\
\hline System $R^{2}=.9404$ & & & & & \\
\hline
\end{tabular}


Population, income and certain other data came from the 1980 census. School stastistics were collected from Facing Up 16, a statistical guide to Virginia public schools. Fire statistics were provided by the Department of Fire Programs and employment statistics by the Virginia Employment Commission. The esitmated models are presented in Table 1.

\section{Conceptual Model of Public Service Provision}

Local governments are responsible for the provision of services not usually provided by private entrepreneurs (Boadway and Wildasin, 1984). In most cases, these services:

1) are subject to declining average costs, and a private firm would lose money if it equated marginal cost and price;

2) involve investments which are large relative to the population to be served, and competition among private firms is unlikely;

3) are such that consumers cannot be easily or cheaply excluded from receiving benefits from the service or facility.

Government officials are both producers and surrogate buyers of these services. While there are a number of theories which deal with the bases for local government decision-making, most agree that governments simultaneously consider the diminishing marginal utility that their constituents receive with each additional unit of the public service, the cost of providing the public service, and the non-local revenue they receive for the provision of that service.

\section{Expenditures}

Following Hirsch (1970 and 1977), the average cost function for public services is derived from a technological relationship (production function). Average cost is, therefore, a function of quantity, quality, input factors, and factor input prices. However, a review of previous studies of the provision of particular public services, such as police and education services, suggests modifications to Hirsch's general model. Beaton (1974), Stinson (1978), and Stinson and Lubov (1982) suggest that local governments experience periods of adjustment to changes in service demands. Beaton and Stinson and Lubov suggest that a contracting locality will experience higher average costs than an expanding one. The public infrastructure developed for larger service levels will have institutional constraints and lumpy inputs underutilized in a contractionary period. Stinson (1978) suggests that an expanding public service sector will have production costs influenced by physical plant capacity, service delivery capacity

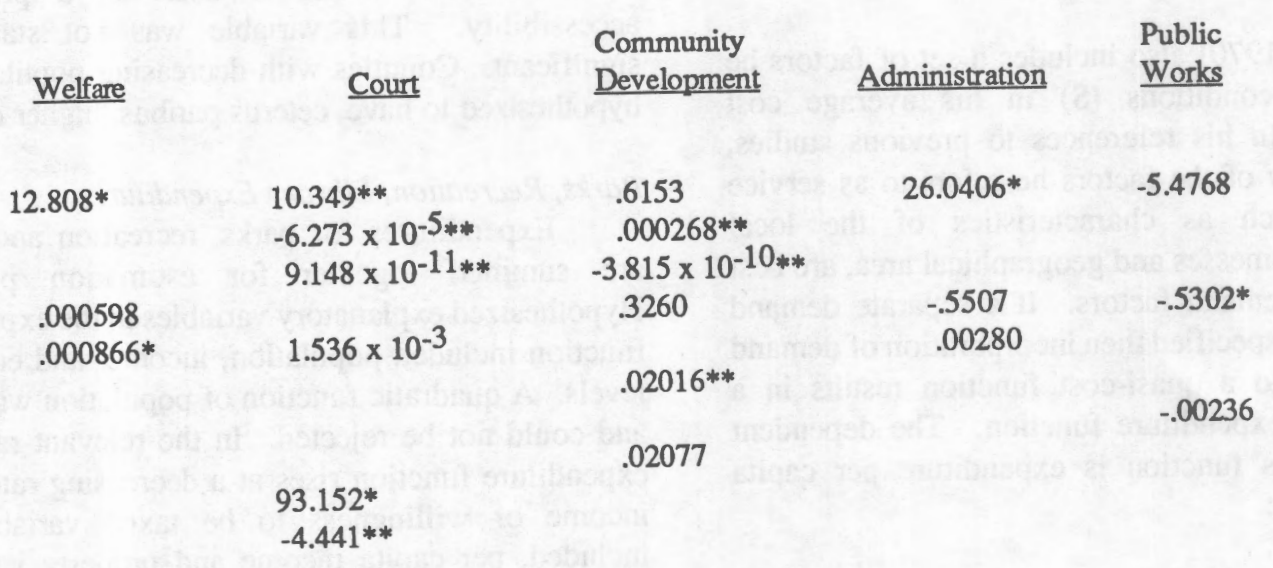


and the choice of production technology.

Many previous studies of public services suggest that economies or diseconomies of size may exist in public service provision. Studies of education by Cohn (1968), Fox (1980), Osburn (1970), and Riew (1966) suggest significant size economies in education provision. Based on the discussion above, the cost function would be as follows:

$$
\mathrm{UC}=\mathrm{a}(\mathrm{Q}, \mathrm{A}, \mathrm{I}, \mathrm{F}, \mathrm{P})
$$

where UC $=$ unit cost of producting public services,

$\mathrm{Q}=$ quality of service,

$\mathrm{A}=$ quantity of service,

$I$ = input factors,

$\mathrm{F}=$ factor input prices, and

$\mathrm{P}=$ rate of change in population.

Empirical estimation of cost functions for particular public services from the generalized function (1) requires definition of the production unit. Problems arise in devising quantities, particularly for services such as welfare and health services. In these cases quasi-cost functions are estimated. Expenditures are estimated on a per capita rather than per unit basis. With cost per capita (CC) the new dependent variable, the quasi-cost function takes the following form:

(2) $\mathrm{CC}=\mathrm{b}(\mathrm{Q}, \mathrm{A}, \mathrm{I}, \mathrm{F}, \mathrm{P})$

where $A$ is redefined as population.

Hirsch (1970) also includes a set of factors he calls service conditions $(S)$ in his average cost formulation. In his references to previous studies, however, many of the factors he refers to as service conditions, such as characteristics of the local population, businesses and geographical area, are best described as demand factors. If a separate demand equation is not specified then incorporation of demand factors (D) into a quasi-cost function results in a reduced form expenditure function. The dependent variable of this function is expenditure per capita (EC) as follows:

(3) $\mathrm{EC}=\mathrm{c}(\mathrm{Q}, \mathrm{A}, \mathrm{I}, \mathrm{F}, \mathrm{P}, \mathrm{D})$.

\section{Non--local Revenues}

Studies by Henderson (1968) and by Horowitz (1968) view local government expenditures as being determined simultaneously by the interaction of cost conditions, local government revenues and non-local government revenues. In this model, local government revenues are assumed to be the residual of expenditures less non-local revenues. Non-local revenues are explained by local factors. State and federal governments are hypothesized to react to local factors in determining their aid to local governments. A general form of the non-local revenue equations is:

\section{Fire Protection Expenditures}

Fire protection expenditures were hypothesized to be a function of crime rates, population, whether manned by professional firefighters, fire protection rating, roads, and population growth. Arson is a major cause of fires.; as arson rates are not reported seperately in crime statistics, of the overall crime rate per capita is used as a proxy. The hypothesis of fire protection being a quadratic expenditure function in population could not be rejected. In the relevant range of population, per capita fire protection expenditures increase at a decreasing rate with population. Lederer and Badenhop (1976) discuss the importance of volunteerism. They estimate the value of fifty volunteer firefighters in Cumberland County, Tennessee. They find that the value of the volunteers is between $\$ 22$ and $\$ 25$ per capita. In this study, we use the ratio of the number of professional to the number of volunteer firefighters as a measure of the extent of volunteerism in the local fire department. A community's fire protection rate is a measure of the quality of fire protection. Increased quality of fire protection (lower numerical rating) will be more costly, ceterus paribus. The more accessible an area is by a network of roads, the lower the costs should be. Miles of roads is used as a proxy for accessibility. This variable was not statistically significant. Counties with decreasing population are hypothesized to have, ceterus paribus, higher costs.

\section{Parks, Recreation, Library Expenditures}

Expenditures for parks, recreation and library are summed together for estimation purposes. Hypothesized explanatory variables in the expenditure function included population, income, and education levels. A quadratic function of population was tested and could not be rejected. In the relevant range the expenditure function rises at a decreasing rate. Two income or willingness to be taxed variables are included, per capita income and property value per capita. Areas with a higher percentage of high school graduates per 100 population should demand greater levels of these services causing higher costs, certerus paribus.

\section{Police Protection Expenditures}

Several previous studies have investigated the determinants of police expenditures. Important factors to be included are population, rate of 
population change, degree of urbanization, quality of service, income, and education.

Previous studies of police expenditures by Beaton (1974) and Stinson and Lubov (1982) found per capita expenditures to increase with population when a linear functional form is assumed. In this study a quadratic form was tested and could not be rejected. For relevant sizes of population, expenditures increase with population but at a decreasing rate.

Beaton suggested two reasons why declining localities might have greater per capita police expenditures than growing localities of the same size. First, declining population and the abandonment of old physical plants by the private sector require greater public protection. Secondly, declining localities will have public service capacity for their former population levels. This capacity will be in terms of physical structures and in terms of bureaucratic infrastructure. Previous studies (Beaton, 1974, Stinson and Lubov, 1982, and Davidson and Havlicek, 1980) have, indeed, found significantly higher costs associated with decreasing versus increasing localities of the same size. In their study, the percentage change in population from the previous year was included in the model. In agreement with the previous studies, per capita expenditures are found to be negatively related to changes in population.

Davidson and Havlicek (1980) hypothesized that per capita police expenditures would be positively related to the level of urban influence in the locality. The hypothesis is that geographic proximity to urban areas influences the level of allocation of revenues to police expenditures. In this study the distance to an SMSA is used as a negative measure of urbanization.

Solved crimes per capita is used as the measure of the quality of local police protection. Two demand factors, the percentage of the population aged 25 or greater with high school diplomas and per capita income were considered.

\section{Correction and Detention Expenditures}

The expenditure function for correction and detention expenditures per capita was hypothesized to be a function of the standard quantity variable, population (a quadratic relationship), the population change variable, and a demand variable, per capita income. Two additional variables, which may be described as service condition or demand variables are the solved crime rate in the locality and the density of the local population.

\section{Education Expenditures Per Pupil}

Deaton and McNamara (1984) have reviewed the considerable literature on education expenditures. Per pupil education expenditure studies most relevant to the current study have been completed by Cohn (1968), Hirsch (1960), Osburn (1970) and Riew (1966). Important determinants of per pupil school expenditures are enrollment, change in enrollment, quality of service, property values and income. Cohn, Osburn and Riew all found significant size economies, a quadratic expenditure function was tested and could not be rejected. The resulting cost function is U-shaped but is downward-sloping in the relevant range. Problems of over-capacity for declining enrollments are expected for schools. Areas with negative percentage changes in enrollment are hypothesized to experience higher costs per capita than those with positive changes. The teacher/pupil ratio is an input factor as well as a proxy for education quality. It is hypothesized that it will be positively related to expenditures. Two measures of local ability to pay for education are property value per capita and per capita income. Hirsch suggested that the ability to pay is the most significant determinant of per pupil expenditures in St. Louis. The estimated models for education expenditures and non-local revenues for education are presented in Table 2.

\section{Health and Welfare Expenditures Per Capita}

Health and welfare expenditures are hypothesized to respond to approximately the same set of factors. Government funded health and welfare care is provided in response to two distinct areas of demand. Low income families are able to take advantage of low cost health care and welfare support. Special infant health care services are more generally provided. Variables included in the expenditure equation attempt to reflect these two distinct factors. They include local need and income. The percentages of the population who are non-white and unemployed proxy local need. In addition, public health services for infants can make significant differences to the local infant mortality rate. Some interdependency of utility functions is hypothesized. Income is therefore a proxy for altruistic demand or willingness to pay.

\section{Court Expenditures Per Capita}

Court expenditures were hypothesized to be dependent upon population, crime rate, and income. A quadratic relationship with population was hypothesized and accepted. Court expenditures were found to decrease with population but at a decreasing 
Table 2

Education Expenditures and Non-Local Revenues

Intercept
Enrollment
Enrollment ${ }^{2}$
$\% \Delta$ Enrollment
Teacher/Pupil Ratio
Property Values/Capita
Income/Capita
Local School Revenues
System $\mathrm{R}^{2}=.9404$
*Indicates significance at the 0.10 level.
**Indicates significance at the 0.01 level.

rate in the relevant range. Expenditures were expected to be dependent upon the local crime rate and the local rate of crime solution. Rather surprisingly, expenditures were found to be negatively related to the solved crime rate, indicating that solved crimes are less costly to handle in the courts than are nonsolved crimes. Not surprisingly, the local crime rate was found to be a positive factor influencing court cost. This result, together with the result that crime rate is a significant determinant of fire protection expenditures, indicate some substitutability of public services. Higher crime rates are associated with higher expenditures on fire and on court services. Court services are hypothesized to be normal goods and therefore to be positively related to per capita income.

\section{Community Development Expenditures Per Capita}

Important determinants of community development expenditures were hypothesized to be population, and property values. A quadratic relationship with population was hypothesized and accepted. The expenditure function increases at a decreasing rate in the relevant range. Property value per capita is used as a proxy for individual and commercial demand for development.

\section{Overhead Expenditures}

Administration and public works are modeled as overhead expenditures dependent on the levels of all other public services. A proxy for the levels of other public services is the sum of their expenditure levels. Therefore, the subtotal (less school) of the previous eight expenditures is used as an agrument in
Non-Local

Expenditures

Revenues

$-317.59 *$

$-.000469$

$3.114 \times 10^{-8}$

$-4.528$

$26.437 * *$

$.3184^{*}$

$.06647 * *$

$1050.94 * *$

$-.00300$

$-.7711$

3.0873

$-.3440$

explaining administration and public works expenditures.

\section{Non-Local Revenues}

Table 3 presents the estimated equations for the non-local revenues. As in the case of expenditures, the equations are of per capita levels. Each was hypothesized to be a function of population, change in population, and various proxies for need, such as per capita income, unemployment, population density. They were also hypothesized to be functions of local revenues allocated to each. The equations in Table 3 include only those variables which were reasonably significant after the first regression runs.

\section{Local Revenues}

Equation (6) presents a budgetary constraint function which forces local government revenues to be determined by the residual of expenditures left after other revenues have been applied.

(ด) $U E * A=(N L R * A)+S T R+(P T R * P T B)$

\section{Sales Tax Revenue (STR)}

Sales tax revenues are a principal component of local revenues and are determined by local sales. Local sales, or since sales tax is fixed at one percent of sales, sales tax, is hypothesized to be a function solely of residentiary employment. The following equation is estimated for 1982 with ordinary least squares.

(7) Salestax $=102,639.20+204.88$ Residentiary employment

$(\mathrm{t})$ : 
Table 3

Non-Local Revenues by Category

\begin{tabular}{|c|c|c|c|c|c|c|}
\hline & $\begin{array}{l}\text { Public } \\
\text { Safety }\end{array}$ & $\begin{array}{l}\text { Parks/ } \\
\text { Recreation }\end{array}$ & $\begin{array}{l}\text { Health/ } \\
\text { Welfare }\end{array}$ & Courts & Administration & $\begin{array}{l}\text { Public } \\
\text { Works }\end{array}$ \\
\hline Intercept & 3.6288 & -1.204 & 7.2318 & $6.2106 * *$ & $26.0406 *$ & $-2.4156^{*}$ \\
\hline Population & $-2.599 \times 10^{-5 * * *}$ & & & & & \\
\hline$\% \Delta$ in Population & $-.8800 * *$ & & -.2331 & & -.5507 & \\
\hline Income/Capita & $.00113^{* *}$ & $2.818 \times 10^{-5}$ & $.002519 * *$ & & & $-.2724 \times 10^{-6}$ \\
\hline Solved Crimes/Capita & $4.7122^{* *}$ & & $.02433^{* *}$ & $-1.314^{*}$ & & \\
\hline Unemployment Rate & $.7900 * *$ & & $.8795^{*}$ & $.1551^{*}$ & & \\
\hline Population Density & & $-3.696 \times 10^{-4}$ & & & & \\
\hline Property Value/Capita & & $.0104 * *$ & & & .00280 & \\
\hline Local H/W Revenue & & & $-.9328 * *$ & & & \\
\hline Retail Sales & & & $-4.276 \times 10^{-4^{*}}$ & & & $6.1618 \times 10^{-4 *}$ \\
\hline Police Exp/Capita & & & & $-.0772 * *$ & & -.0497 \\
\hline Total Exp/Capita & & & & & .0808 & $.10266 * *$ \\
\hline Local P.W./Revenue & & & & & $6.568 \times 10^{-4}$ & $-.4101 * *$ \\
\hline System $R^{2}=.9404$ & & & & & & \\
\hline
\end{tabular}

\section{Property Tax Base (PTB)}

Property values are hypothesized to be a function of business and population levels. In the following equation, total employment is used as a proxy for business level. A quadratic function is hypothesized since the competition for land will push land prices higher as employment increases.

(8) Propval $=53,487+3.7$ Totemp +.00018 Totemp ${ }^{2}+13.732$ POP
$(t):(1.243) \quad(11.6108)$
(15.042)

\section{Conclusion}

The model above is a first step toward the realization of a detailed economic impact model. The fiscal impact model is based on sound theoretical and empirical foundations. The major divergences from other fiscal models include: 1) the incorporation of lags into the expenditure functions, 2) the estimation of non-linear (quadratic) average cost curves, 3 ) the incorporation of quality measures for public services, 4) the estimation of non-local revenue equations, 5) the use of proxy variables for political influence and local/non-local spending formulae, and 6) use of seemingly unrelated estimation techniques to estimate expenditure and revenue equations as a system.

The lags (measured by the effect of rate of growth) proved to be an important feature of several models. The coefficients support the hypothesis that

expenditures are "sticky" and do not change as quickly as population. This aspect is important to impact analyses involving growth or decline. Ironically, the lag structure estimated here is somewhat inadequate for large, instantaneous changes such as annexations since the population change variable is required to extrapolate too far. Additional analysis of the dynamics of the expenditure process are suggested by this study.

Six of the eleven expenditure categories (including education) exhibited non-linearity with respect to size. The remaining five demonstrated no systematic relationship to size at all. In four of the six non-linear categories, average costs increased at a decreasing rate while the fifth and sixth categories (courts and education) were U-shaped. This finding suggests that for the counties studied, overall size economies do not exist. However, this conclusion must remain tentative since these equations are reduced form and do not separate the effects of costs from those of demand.

Higher quality fire and police protection both require larger expenditures per capita as expected. In other services, more work is needed to adequately measure quality. Property value per capita (a proxy for political power) was highly significant and positive in four of the seven non-local revenue equations. This relationship suggests that political influence is a very real aspect of intergovernmental 
transfers. In those non-local revenue equations where expenditures from local sources were significant, the coefficients were negative indicating a substitutibility between sources of funds rather than a matching of funds.

The fiscal model above is but one point in a continuous evolutionary process. Demographic and economic components must be added and the fiscal component improved. This model also must be validated, but the statistical results are very encouraging.

\section{REFERENCES}

Beaton, W. Patrick. "The Determinants of Police Protection Expenditures." National Tax Journal. 24 (1974). 335-349.

Boadway, Robin W. and David E. Wildasin. Public Sector Economics. Boston: Little, Brown and Company, 1984.

Cohn, Elchanan. "Economies of Scale in Iowa High School Operations." Journal of Human Resources. 3:4 (1968). 422-434.

Davidson, V. Agnes and Joseph Havlicek. "Provision of Public Services: Demographic, Social and Economic Determinants." Blacksburg, Virginia: Department of Agricultural Economics, Virginia Polytechnic Institute and State University, January 1980.

Deaton, Brady J. and Kevin T. McNamara. "Education in a Changing Environment: Impact of Population and Economic Change on the Demand and Cost of Public Education in Rural America." Southern Rural Development Center, Bibliography Series \#18 (1984).

Fox, William F. "Relationships Between Size of Schools and School Districts and the Cost of Education." U.S. Department of Agriculture, Economics, Statistics and Cooperatives Service, Technical Bulletin No. 1621 (1980).

Halstead, John M. and Thomas G. Johnson. "Fiscal Impact Models for Local Economies." Journal of Applied Business Research 3 (Spring 1986). 90101.

Henderson, James M. "Local Government Expenditures: A Social Welfare Analysis." The Review of Economics and Statistics. 50:2 (May 1968). 156163.
Hirsch, Wemer Z. "Determinants of Public Education Expenditures." National Tax Journal. 13:1 (1960). 29-40.

Economics of State and Local

Government. New York: McGraw-Hill, 1970. . "Output and Costs of Local

Government Services." Paper for the National

Conference on Non-Metropolitan Community

Services Research, Ohio State University,

Columbus, Ohio. (January 21, 1977).

Horowitz, Ann R. "A Simultaneous-Equation Approach to the Problem of Explaining Interstate Differences in State and Local Government Expenditures." The Southern Economic Journal. 13:4 (April 1968). 459-476.

Lederer, Thomas H. and Merton B. Badenhop. "Voluntary Effort as a Tax Substitute in the Revenue-Sharing Allocation Formula." Southern Journal of Agricultural Economics. 8:1 (July 1976). 217-220.

Osburn, Donald D. "Economies of Size Associated with Public High Schools." Review of Economics and Statistics. 52:1 (1970). 113-115.

Pindyck, Robert S. and D.L. Rubinfeld. Econometric Models and Economic Forecasts. New York: McGraw-Hill, 1976.

Riew, John "Economies of Scale in High School Operation, (Wisconsin)." Review of Economics and Statistics. 48:3 (1966). 280-287.

Stinson, Thomas F. "The Dynamics of the Adjustment Period in Rapid Growth Communities." Prepared for Presentation at the WAEA Annual Meeting, Bozeman, Montana. (July 24, 1978). . and Andrea Lubov. "Segmented

Regression, Threshold Effects, and Police Expenditures in Small Cities." American Journal of Agricultural Economics. 64:4 (November 1982). 738-746.

U.S. Census. "Summary Tape File 4, Documentation Supplement 1, Tabulation P-B34, Place of Work." 1980.

Virginia Department of Education. "Facing Up 16: Statistic Data on Virginia's Public Schools, 1980 81 School Year." March 1982.

Virginia Department of Fire Programs. "Results of the Fire Department Personnel Survey." December 1983.

Virginia Employment Commission. "Covered Employment and Wages in Virginia by 2-Digit SIC Industry." Various dates. 